\title{
Research on Relationship between Body Composition and Muscle Force and Bone Mineral Density of College Students in Liaoning Province
}

\author{
Fengbin Liu \\ College of Physical Education \\ Dalian University \\ Dalian, China 116622
}

\begin{abstract}
With the improvement of health consciousness, people pay more attention to their health condition. As a common chronic disease, osteoporosis has caused health problems and extensive concerns. College students are the main force to build well-off society in an all-around way and realize socialist modernization. Attentions are paid to their health condition. According to the bone mineral density (BMD) of college students, body composition and muscle force of college students of different sexes in PE major and non-PE major are tested. Influence factors of osteoporosis are analyzed comprehensively. The relationship between body composition, muscle force and BMD of college students in the important period of growth and development is discussed, in order to provide theoretical and practical basis for prevention and evaluation of osteoporosis.
\end{abstract} BMD

Keywords - college students; body composition; muscle force;

\section{INTRODUCTION}

With economic development and improvement of people's living standard, people attach more importance to their health conditions. As the common chronic disease of people especially old people and women around the menopause, osteoporosis receives attentions of experts and scholars in medical science, health and sports. The most effective method of preventing osteoporosis is to improve the peak bone mass in early adulthood. The period around the puberty is crucial for BMD development. The acquisition of high BMD in this period plays an important role in preventing osteoporosis, referring to one of the important measures to prevent senile osteoporosis. [1-3]

According to researches, constitution and health conditions of college students decline in recent years. The group is in the key period of increasing bone mass. It has important practical significance on preventing osteoporosis and chronic disease through testing the changes of college students' BMD and monitoring their bone content. The research analyzes the relationship between lean body mass, mass of body fat and BMD of college students through measuring BMD and body composition of college students, and discusses the relationship between body composition and BMD of college students, in order to provide theoretical and practical basis for prevention and evaluation of osteoporosis

\section{RESEARCH OBJECTS AND METHODS}

\section{A. Research Objects}

The research objects include 90 sophomores in PE major of school of physical education in a university of Liaoning Province, including 51 male students and 39 female students; 110 sophomores in school of information, including 70 male students and 40 female students. Basic information of subjects is shown in "Table I". Research objects haven't taken medicines that influence bone metabolism and have meals in the same canteen. It avoids the disturbance caused by different eating environment.

TABLE I. GENERAL CONDITION OF SUBJECTS

\begin{tabular}{llccc}
\hline \multicolumn{1}{c}{ Group } & $\begin{array}{c}\text { Numb } \\
\text { er of } \\
\text { people }\end{array}$ & $\begin{array}{c}\text { Age } \\
(\mathbf{y})\end{array}$ & $\begin{array}{c}\text { Height } \\
(\mathbf{c m})\end{array}$ & $\begin{array}{c}\text { Weight } \\
(\mathbf{k g})\end{array}$ \\
\hline $\begin{array}{l}\text { Male students in } \\
\text { PE major }\end{array}$ & 51 & $21.17 \pm 1.11$ & $176.29 \pm 4.45$ & $67.77 \pm 7.10$ \\
$\begin{array}{l}\text { Female students } \\
\text { in PE major }\end{array}$ & 39 & $20.76 \pm 0.81$ & $163.61 \pm 3.97$ & $54.95 \pm 5.27$ \\
$\begin{array}{l}\text { Male students in } \\
\text { non-PE major }\end{array}$ & 70 & $20.64 \pm 0.71$ & $171.06 \pm 5.83$ & $60.01 \pm 9.33$ \\
$\begin{array}{l}\text { Female students } \\
\text { in non-PE major }\end{array}$ & 40 & $20.80 \pm 1.02$ & $158.47 \pm 5.34$ & $50.27 \pm 5.55$ \\
\hline
\end{tabular}

\section{B. Test Instruments and Indicators}

BMD is tested by Sahara Clinical Bone Sonometer of American HOLOGIC Company. Testing position is calcaneus of left foot. Test indicators include speed of sound (SOS), broadband ultrasonic attenuation (BUA), quantitative ultrasound index and BMD.

Body composition is tested by Korean Biospace InBody3.0 body composition analyzer. Test indicators include protein $(\mathrm{P})$, minerals (M), MBF, SLBM, LBM, PBF, OD and BMI.

Muscle force is tested by DW-AL419 series student physical fitness test equipment made in China. Test indicators include grip strength of left and right hands, back strength and standing broad jump. 


\section{Mathematical Statistics and Analysis}

All data are processed by SPSS For Windows 15.0 statistical software. Test results are shown by mean value \pm standard deviation. If it appears homogeneity of variance in testing differences between two samples, test through independent sample $t$; if it appears heterogeneity of variance, test through t'. The correlation between two samples is tested through Pearson correlation analysis. $\mathrm{P}<0.05$ indicates significant difference exists. $\mathrm{P}<0.01$ indicators very significant difference exists.

\section{EXPERIMENTAL RESULTS}

\section{A. Comparison of BMD of College Students}

As shown in "Table II", the indicators of QUI, BMD, BUA and SOS of male students in PE major are significantly higher than that of male students in non-PE major $(\mathrm{P}<0.01)$; the indicators of female students in PE major and non-PE major have no much difference. Meanwhile, the differences of BMD indicator value between female and male students in PE major, between female and male students in non-PE major are not significant $(\mathrm{P}>0.05)$.

TABLE II. COMPARISON OF BMD RESUlt OF COLLEGE STUdENTS

\begin{tabular}{|c|c|c|c|c|}
\hline \multirow{2}{*}{$\begin{array}{c}\text { BMD } \\
\text { indicato } \\
\mathbf{r} \\
\end{array}$} & \multicolumn{2}{|c|}{ Male students } & \multicolumn{2}{|c|}{ Female students } \\
\hline & PE major & $\begin{array}{l}\text { Non-PE } \\
\text { major }\end{array}$ & PE major & $\begin{array}{c}\text { Non-PE } \\
\text { major }\end{array}$ \\
\hline $\begin{array}{l}\text { QUI } \\
(\%)\end{array}$ & $\begin{array}{l}126.59 \pm 20.95 \\
* *\end{array}$ & $\begin{array}{l}109.78 \pm 17 \\
19\end{array}$ & $\begin{array}{l}\text { 128.13 } 22.15 \\
\text { \#\# }\end{array}$ & $\begin{array}{l}104.34 \pm 21 . \\
28\end{array}$ \\
\hline $\begin{array}{l}\text { BMD } \\
(\mathrm{g} / \mathrm{cm} 2\end{array}$ & $0.73 \pm 0.13^{* *}$ & $0.62 \pm 0.11$ & $0.73 \pm 0.14 \# \#$ & $0.59 \pm 0.11$ \\
\hline $\begin{array}{l}\text { BUA } \\
(\mathrm{dB} / \mathrm{M} \\
\mathrm{Hz})\end{array}$ & $\begin{array}{l}101.50 \pm 18.91 \\
* *\end{array}$ & $\begin{array}{l}90.29 \pm 14.0 \\
8\end{array}$ & $\begin{array}{l}105.81 \pm 18.44 \\
\# \#\end{array}$ & $\begin{array}{l}86.86 \pm 15.2 \\
2\end{array}$ \\
\hline $\begin{array}{l}\text { SOS } \\
(\mathrm{m} / \mathrm{s})\end{array}$ & $\begin{array}{l}1608.04 \pm 55.8 \\
6 * *\end{array}$ & $\begin{array}{l}1569.79 \pm 29 \\
.08\end{array}$ & $\begin{array}{l}\text { 1599.77士36.4 } \\
\text { 9\#\# }\end{array}$ & $\begin{array}{l}1563.55 \pm 27 \\
.87\end{array}$ \\
\hline
\end{tabular}

\section{B. Comparison of Body Composition of College Students}

As shown in "Table III", in the male group, the indicators of P, M, SLBM, LBM, W and BMI of students in PE major are higher than that of students in non-PE major, and very significant difference exists $(\mathrm{P}<0.01)$; the $\mathrm{PBF}$ indicator of students in PE major is lower than that of students in non-PE major, and very significant difference exists $(\mathrm{P}<0.01)$; no significant difference exists between the two groups on indicators of $\mathrm{MBF}$ and $\mathrm{OD}(\mathrm{P}>>0.05)$. In the female groups, no significant difference exists in MBF, OD and BMI ( $\mathrm{P}>0.05)$; the indicators of P, M, SLBM, LBM and $\mathrm{W}$ of students in PE major are higher than that of students in non-PE major, and very significant difference exists between the groups $(\mathrm{P}<0.01)$; the PBF indicator of students in PE major is lower than that of students in non-PE major, and very significant difference exists $(\mathrm{P}<0.01)$

TABLE III. COMPARISON OF BODY COMPOSITION RESULT OF COLLEGE STUDENTS

\begin{tabular}{|c|c|c|c|c|}
\hline \multirow[b]{2}{*}{ Indicator } & \multicolumn{2}{|c|}{ Male students } & \multicolumn{2}{|c|}{ Female students } \\
\hline & PE major & $\begin{array}{c}\text { Non-PE } \\
\text { major }\end{array}$ & PE major & $\begin{array}{l}\text { Non-PE } \\
\text { major }\end{array}$ \\
\hline$P(\mathrm{~kg})$ & $11.49 \pm 1.19 * *$ & $9.93 \pm 1.31$ & $8.42 \pm 0.71 \# \#$ & $7.18 \pm 0.62$ \\
\hline $\mathrm{M}(\mathrm{kg})$ & $3.66 \pm 0.29 * *$ & $3.26 \pm 0.35$ & $2.84 \pm 0.19 \# \#$ & $2.53 \pm 0.16$ \\
\hline $\begin{array}{l}\mathrm{MBF} \\
(\mathrm{kg})\end{array}$ & $10.28 \pm 2.64$ & $9.87 \pm 3.80$ & $12.69 \pm 2.6$ & $13.77 \pm 3.2$ \\
\hline $\begin{array}{c}\text { SLBM } \\
(\mathrm{kg})\end{array}$ & $53.84 \pm 5.27 * *$ & $46.87 \pm 6.17$ & $39.43 \pm 3.37 \# \#$ & $34.04 \pm 2.89$ \\
\hline $\begin{array}{l}\mathrm{LBM} \\
(\mathrm{kg})\end{array}$ & $57.49 \pm 5.57 * *$ & $50.13 \pm 6.52$ & $42.26 \pm 3.56 \# \#$ & $36.58 \pm 3.06$ \\
\hline W (kg) & $67.77 \pm 7.09 * *$ & $60.01 \pm 9.33$ & $54.95 \pm 5.27 \# \#$ & $50.34 \pm 5.55$ \\
\hline $\begin{array}{l}\mathrm{PBF} \\
(\%)\end{array}$ & $15.06 \pm 2.83 * *$ & $16.10 \pm 3.89$ & $22.94 \pm 3.29 \# \#$ & $27.07 \pm 3.88$ \\
\hline $\mathrm{OD}(\%)$ & $98.43 \pm 9.11$ & $94.24 \pm 11.39$ & $97.45 \pm 7.8$ & $97.98 \pm 11.19$ \\
\hline $\begin{array}{l}\text { BMI } \\
(\mathrm{kg} / \mathrm{m} 2)\end{array}$ & $21.79 \pm 1.98 * *$ & $20.45 \pm 2.53$ & $20.51 \pm 1.63$ & $20.13 \pm 2.16$ \\
\hline
\end{tabular}

\section{Analysis Results of BMD and Body Composition of College Students' Calcaneus}

As shown in "Table IV" and "Table V", indicators of $\mathrm{P}$, SLBM and LBM that reflect LBM in BMD of calcaneus and body position of students in PE major have positive correlation $(\mathrm{P}<0.05)$. Linear correlation only exists between BMD of calcaneus and weight of female group in $\mathrm{PE}$ major $(\mathrm{P}<0.05)$. The BMD of calcaneus and weight, BMI in other groups haven't linear correlation $(\mathrm{P}>0.05)$. The correlation difference between BMD of calcaneus and MBF, PBF of students in PE major is not significant $(\mathrm{P}>0.05)$. The analysis result indicates the correlation difference between BMD of calcaneus and body composition of students in non-PE major is not significant $(\mathrm{P}>0.05)$

TABLE IV. ANAlysis Result BetweEn BMD AND Body COMPOSITION OF College StUdents IN PE MAJOR

\begin{tabular}{|c|c|c|c|c|c|c|c|c|}
\hline \multirow{2}{*}{ Indicator } & \multicolumn{4}{|c|}{ Male students } & \multicolumn{4}{|c|}{ Female students } \\
\hline & QUI & $B M D$ & $\overline{B U A}$ & SOS & $Q U I$ & $B M D$ & $\boldsymbol{B U A}$ & SOS \\
\hline $\mathrm{P}$ & $0.292 *$ & $0.295^{*}$ & $0.297 *$ & $0.290 *$ & $0.313^{*}$ & $0.314 *$ & $0.350^{*}$ & $0.301 *$ \\
\hline M & $0.285^{*}$ & $0.285^{*}$ & $0.289 *$ & $0.282 *$ & $0.313^{*}$ & $0.314 *$ & $0.315^{*}$ & $0.303^{*}$ \\
\hline MBF & 0.012 & 0.060 & 0.023 & -0.096 & -0.190 & -0.196 & -0.149 & -0.203 \\
\hline SLBM & $0.295^{*}$ & $0.286^{*}$ & $0.290 *$ & $0.287^{*}$ & $0.311^{*}$ & $0.312 *$ & $0.313^{*}$ & $0.300 *$ \\
\hline LBM & $0.297 *$ & $0.286^{*}$ & $0.290^{*}$ & $0.289 *$ & $0.310^{*}$ & $0.311^{*}$ & $0.313^{*}$ & $0.299 *$ \\
\hline W & 0.196 & 0.123 & 0.219 & 0.171 & $0.302 *$ & $0.306^{*}$ & $0.283^{*}$ & $0.300 *$ \\
\hline $\mathrm{H}$ & 0.163 & 0.086 & 0.233 & 0.062 & 0.185 & 0.184 & 0.177 & 0.187 \\
\hline PBF & 0.115 & 0.136 & 0.146 & 0.046 & -0.069 & -0.075 & -0.021 & -0.088 \\
\hline OD & -0.105 & -0.085 & -0.076 & -0.153 & -0.199 & -0.204 & -0.183 & -0.196 \\
\hline BMI & 0.137 & 0.102 & 0.122 & 0.165 & 0.242 & 0.248 & 0.225 & 0.240 \\
\hline
\end{tabular}


TABLE V. ANALysis Result BetweEn BMD and Body Composition of COLLEGE STUDENTS IN NON-PE MaJoR

\begin{tabular}{lllllllll}
\hline \multirow{2}{*}{ Indicator } & \multicolumn{4}{c}{ Male students } & \multicolumn{5}{c}{ Female students } \\
\cline { 2 - 9 } & $\boldsymbol{Q} \boldsymbol{U} \boldsymbol{I}$ & $\boldsymbol{B} \boldsymbol{M D}$ & $\boldsymbol{B U} \boldsymbol{A}$ & $\boldsymbol{S O S}$ & $\boldsymbol{Q U I}$ & $\boldsymbol{B} \boldsymbol{M} \boldsymbol{B}$ & $\boldsymbol{B} \boldsymbol{A}$ & $\boldsymbol{S} \boldsymbol{O S}$ \\
\hline P & 0.08 & 0.086 & 0.160 & 0.047 & 0.060 & 0.209 & 0.100 & 0.240 \\
M & 0.064 & 0.071 & 0.143 & 0.034 & 0.078 & 0.229 & 0.126 & 0.255 \\
MBF & -0.028 & -0.027 & -0.044 & -0.060 & -0.072 & -0.011 & -0.080 & -0.073 \\
SLBM & 0.065 & 0.072 & 0.143 & 0.034 & 0.072 & 0.225 & 0.122 & 0.251 \\
LBM & 0.065 & 0.071 & 0.143 & 0.034 & 0.072 & 0.224 & 0.123 & 0.251 \\
W & 0.033 & 0.039 & 0.118 & 0.001 & 0.000 & 0.133 & 0.024 & 0.184 \\
H & 0.153 & 0.154 & 0.072 & 0.190 & 0.035 & 0.174 & 0.135 & 0.178 \\
PBF & -0.057 & -0.059 & -0.008 & -0.082 & 0.124 & 0.088 & 0.161 & 0.022 \\
OD & 0.156 & 0.163 & 0.190 & 0.146 & 0.049 & 0.028 & 0.102 & 0.019 \\
BMI & 0.126 & 0.132 & 0.176 & 0.107 & 0.039 & 0.013 & 0.074 & 0.064 \\
\hline
\end{tabular}

\section{Analysis Results between BMD and Muscle Force of College Students}

As shown in "Table 6" and "Table 7", BMD and standing broad jump in male group of PE major have positive correlation, and the difference is significant $(\mathrm{P}<0.05)$. The correlation differences of QUI, BUA, SOS and grip strength of left and right hands and back strength are not significant $(\mathrm{P}>0.05)$; the correlation differences of QUI, BMD, BUA, SOS and muscle force of female students in PE major are not significant. In the male group of non-PE major, back strength and QUI, BMD have positive correlation, and the difference is significant $(\mathrm{P}<0.05)$; BUA and back strength have positive correlation, and the difference is very significant $(\mathrm{P}<0.01)$; the correlation difference of other indicators is not significant $(\mathrm{P}>0.05)$. In the female group, the correlation difference between BMD and muscle force is not significant $(\mathrm{P}>0.05)$.

TABLE VI. Result Between BMD and Muscle Force of College Students in PE MAJOR

\begin{tabular}{lcccccccc}
\hline \multirow{2}{*}{ Indicator } & \multicolumn{3}{c}{ Male students } & \multicolumn{5}{c}{ Female students } \\
\cline { 2 - 8 } & $\boldsymbol{Q U I}$ & $\boldsymbol{B M D}$ & $\boldsymbol{B U A}$ & $\boldsymbol{S O S}$ & $\boldsymbol{Q U I}$ & $\boldsymbol{B M D}$ & $\boldsymbol{B U A}$ & $\boldsymbol{S O S}$ \\
\hline Grip strength of left hand & 0.050 & 0.038 & 0.045 & 0.076 & 0.133 & 0.135 & 0.164 & 0.112 \\
Grip strength of right hand & 0.040 & 0.021 & 0.012 & 0.119 & 0.083 & 0.083 & 0.100 & 0.064 \\
Back strength & 0.062 & 0.035 & 0.007 & 0.103 & 0.158 & 0.159 & 0.168 & 0.152 \\
Standing broad jump & 0.261 & $0.292^{*}$ & 0.218 & 0.234 & 0.092 & 0.090 & 0.149 & 0.086 \\
\hline
\end{tabular}

Note: * shows the correlation comparison between indicators, $\mathrm{P}<0.05$.

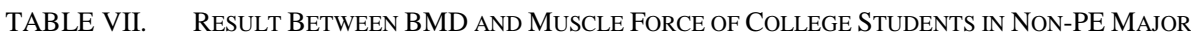

\begin{tabular}{|c|c|c|c|c|c|c|c|c|}
\hline \multirow{2}{*}{ Indicator } & \multicolumn{3}{|c|}{ Male students } & \multicolumn{5}{|c|}{ Female students } \\
\hline & QUI & $B M D$ & $B U A$ & SOS & $Q U I$ & $B M D$ & $\boldsymbol{B U A}$ & SOS \\
\hline Grip strength of left hand & 0.176 & 0.178 & 0.201 & 0.162 & 0.039 & 0.190 & 0.172 & 0.198 \\
\hline Grip strength of right hand & 0.184 & 0.194 & 0.231 & 0.169 & 0.038 & 0.075 & 0.091 & 0.068 \\
\hline Back strength & $0.317^{*}$ & $0.326^{*}$ & $0.397 * *$ & 0.282 & 0.069 & 0.000 & 0.025 & 0.038 \\
\hline Standing broad jump & 0.039 & 0.031 & 0.023 & 0.058 & 0.223 & 0.230 & 0.153 & 0.258 \\
\hline
\end{tabular}

\section{DISCUSSION AND ANALYSIS}

\section{A. Influences of Exercise on BMD of College Students' Calcaneus}

When researching the rules of bone change, the foreign scholar Wollf proposes, "each interconversion of bone function shows certain changes of internal structure and external forms corresponding to mathematical rules". Wollf law emphasizes mechanical changes determine the forms and construction of bones. About more than 90 percent of bone mass of people in lifetime acquires before 20 , and it peaks before 30 years old. Research shows [4,5], physical activities in people's early years can increase peak bone mass. Male and female are alike. Regular exercise especially load exercise helps to increase peak bone mass.

The research result shows compared with students in nonPE major, the indicators of QUI, BMD, BUA and SOS of students in $\mathrm{PE}$ major increase significantly $(\mathrm{P}<0.01)$. It indicates systematic physical exercise can facilitate BMD of human, improve sclerotin and increase BMD, laying foundation for the maintenance of good sclerotin in adulthood. The index values of BMD between male and female students in PE major, between male and female students in non-PE major are not different $(\mathrm{P}>0.05)$ It indicates the changes of $\mathrm{BMD}$ of calcaneus of young people have no significant gender difference. The increase of BMD caused by exercises doesn't show significant gender difference. It indicates exercises can promote the increase of BMD of college students. It is different from the previous researches. It may be because the measurement methods and the position for evaluation of BMD are different.

\section{B. Influences of Exercise on College Students' Body Composition}

Researches at home and abroad show [6, 7] the body composition of people is affected by many factors. Exercise and nutrition play important roles in it. The research also reaches the similar conclusion. It shows BMI values of college students in PE and non-PE majors are within the moderate range determined by WHO. It indicates the weights of subjects are within the good range. According to the results of body 
composition, when the BMI is in the normal range, the indicator of body composition between students in different major, and between different genders of the same major has significant difference. Body compositions of students in different majors are different. In the male group, the indicators of P, M, SLBM, LBM, W and BMI of students in PE major are higher than that of students in non-PE major, and the difference is very significant $(\mathrm{P}<0.01)$; the PBF indicator of students in $\mathrm{PE}$ major is lower than that of students in non-PE major, and the difference is very significant $(\mathrm{P}<0.01)$; differences in $\mathrm{MBF}$ and OD indicators are not significant $(\mathrm{P}>0.05)$. The reason is that frequent physical exercise can improve body composition and increase protein in body composition, which greatly increase the proportion of LBM in body composition. Although the MBF of male students in different majors is not different, the proportion of body fat of male students in non-PE major is higher than that of male students in non-PE major. The result conforms to the change rule on body composition. In the female group of different majors, the changes of body composition are the same with male group. Except for no significance in MBF, OD and BMI $(\mathrm{P}>0.05)$ in the two female groups, the indicators of P, M, SLBM, LBM and $\mathrm{W}$ of students in PE major are higher than that of non-PE major and have very significant difference $(\mathrm{P}<0.01)$; the $\mathrm{PBF}$ indicator of students in PE major is lower than that of students in non-PE major and has very significant difference $(\mathrm{P}<0.01)$. It indicates exercises can improve body composition of female college students, increase the contents of LBM in body composition and lower the MBF.

According to the results through comparing body composition between female and male students in the same major, except for no significance in OD $(\mathrm{P}>0.05)$, the differences in other indicators in two groups of $\mathrm{PE}$ major are significant $(\mathrm{P}<0.01)$; the differences of students in non-PE major and PE major are almost the same. BMI indicator has no significant difference $(\mathrm{P}>0.05)$. The research result shows the body composition of female and male students in the same major has significant gender difference. The LBM of female students is significantly lower than male students, but the MBF and proportion of body fat of female students are significantly higher than male students. It conforms to the differences of female and male on body composition and indicates although female and male students have different body composition through physical exercises, exercise can significantly influence the body composition and make the component proportion of body composition more reasonable, improve health and prevent some diseases.

\section{Correlation Analysis on BMD of Calcaneus and Body Composition of College Students}

Many researches at home and abroad have proved [8, 9] that weight and LBM can promote bone mass. The effect of weight gain on increasing BMD may be the effect of loadbearing external force on bone. LBM increase may be the primary determinant for increase of BMD of the whole body and BMD in lumbar vertebra. Compared with fat mass, LBM can better predict BMD. Recently, researches indicate [7, 10] regardless of gender and age, the relation between LBM and BMD is closer than that between LBM and body composition.
LBM in body composition of young male greatly influences BMD in far end of radius. LBM and BMD of male and female have significant positive correlation. Adipose tissue and BMD of female have correlation. The bone mineral contents of obese children are significantly higher than that of normal children, but LBM plays a decisive role in bone mineral contents.

The research result indicates in female and male groups of PE major, positive correlation exists between BMD of calcaneus and indicators of P, SLBM and LBM that reflect LBM in body composition. LBM relates to BMD of calcaneus of college students. LBM has greater relationship with BMD in body composition of young students. The frequent physical exercise in adolescence can increase LBM and BMD. Because college students in non-PE major lack systematic physical exercise, the indicators of SLBM, LBM and W are lower than students in PE major. It causes the low degree of correlation of college students in non-PE major in LBM and BMD. Furthermore, although $\mathrm{M}$ represents the contents of minerals in human body, the results show the $\mathrm{M}$ value of college students with frequent physical exercise relates to BMD of calcaneus. We can evaluate the sclerotin through measuring minerals in human body according to body composition. At the meantime, linear correlation exists between BMD of calcaneus and weight of female students in $\mathrm{PE}$ major $(\mathrm{P}<0.05)$. No linear correlation exists between BMD of calcaneus and weight, BMI in other groups $(\mathrm{P}>0.05)$. It is different from the previous researches. The reasons are as follows: on one hand, BMI of college students is within normal range, and the proportion of deviation of BMI value in the indicators measured is very small, so the relationship between BMI and BMD is not discussed through grouping; on the other hand, the bone mass of college students hasn't peaked. It lacks accuracy through taking weight or BMI as evaluation indicators that influence the BMD of human body. However, researches also show the weight of female students is an important factor that influences the BMD of calcaneus. It is necessary for female to gain weight in adolescence.

Because osteoporosis often happens among old people, especially the female, the previous researches $[4,7]$ focus on women around the menopause and think the MBF and BMD of women before menopause have significant correlation. Compared the LBM, MBF can better predict the BMD of women before menopause; compared with women after menopause, women before menopause have more significant correlation between bone mineral and body fat proportion; compared with people with normal or light weight, obese people have higher BMD. After the multiple stepwise regression analysis on 234 adolescents between eight and sixteen years old, Faulkner [13] finds body fat and BMD have no significant correlation. The research results indicate the correlation difference between BMD of calcaneus and MBF, PBF of male and female students in PE major is not significant $(\mathrm{P}>0.05)$. The analysis on BMD of calcaneus and body composition of male and female students in non-PE major also indicates the correlation difference of them is not significant $(\mathrm{P}>0.05)$. The above results indicate the correlation between MBF and BMD of college students is not high, and the result tends to LBM. The reason may be because the weight and BMI of college students are within the normal range, and the MBF has no big influence on BMD. The relationship between LBM 
and BMD of college students indicates college students should increase LBMM to increase BMD.

\section{Correlation Analysis on BMD and Muscle Force of College Students}

Previous researches indicate [12, 13] BMD relates to muscle force. Muscle force determines bone structure and bone mass to make bone strength adapt to exercise load; muscle in body composition plays a decisive role in BMD. The influence of muscle on BMD is first caused by dynamic load namely muscle force and then caused by gravity produced by static load namely the muscle. Domestic scholars [14] take 1,109 female between 39 and 65 years old as the research objects and find BMD of femoral neck and muscle force of lower limbs have significant positive correlation and think the muscle force of lower limbs can influence BMD. The research on 1,462 people above 20 years old shows the weight, grip force and BMD of urban and rural people have significant positive correlation, meanwhile, muscle force and weight significantly influence BMD.

The research also draws similar conclusion. BMD and standing broad jump of male group in PE major have positive correlation $(\mathrm{P}<0.05)$, indicating $\mathrm{BMD}$ of male students in $\mathrm{PE}$ major relates to muscle force of lower limbs; however, the back strength and BMD of male students in non-PE major have positive correlation $(\mathrm{P}<0.05)$, indicating $\mathrm{BMD}$ of male students in non-PE major relates to muscle force on the back. In the female group, the difference between indicators of BMD and muscle force is not significant $(\mathrm{P}>0.05)$, indicating the BMD has no significant correlation with muscle force in the female group. The above results indicate with the increase of LBM, the muscle force of human body also increases, which will influence BMD. The influence degree on BMD relates to development level of LBM and muscle force. For male students, the back strength of them without frequent exercise closely relates to BMD; the strength of lower limbs of them with frequent exercise closely relates to BMD. But for female students, although physical exercise can change LBM and increase muscle force, the changes of overall muscle force are small, so it has no significant correlation with BMD.

\section{CONCLUSION}

- Physical exercise can increase BMD of calcaneus of college students; the BMD of calcaneus between male and female students in the same major is not different. The increase of BMD of calcaneus of students in the same major through exercise has no gender difference.

- The difference in BMD of calcaneus of students in different majors does not relate to eating and living habits but relate to physical exercise and exercise habit.

- Exercise can increase the contents of LBM in body composition of college students, decrease the proportion of body fat and make the component proportion of body composition more reasonable. College students should improve body composition to increase BMD through frequent physical exercise.
- BMD of calcaneus relates to LBM in body composition of college students. But MBF and the proportion of body fat have nothing to do with BMD of calcaneus. The increase of BMD of calcaneus among female students relates to the weight gain.

- Muscle force relates to BMD of calcaneus of male college students, but college students with different exercise degree are different in the correlation degree between muscle force and BMD of calcaneus. Physical exercise will increase LBM and muscle force of female students, but unlike male students, the muscle force has no relationship with BMD of calcaneus among female students.

\section{REFERENCES}

[1] Zhang Zhihai, Liu Zhonghou, Shi Shaohui. Retrospective Study of Literature on Osteoporosis Morbidity Diagnosed by -2.5SD in Mainland China [J], Chinese Journal of Osteoporosis, 2015, 21 (1): 1-8

[2] ZHANG Z Q,HO S C, CHEN Z Q, et al. Reference values of bone mineral density and prevalence of osteoporosis in Chinese adults[J].Osteoporosis international: a journal established as result of cooperation between the European Foundation for Osteoporosis and the National Osteoporosis Foundation of the USA,2014,25(2):497-507.

[3] R OGHANI $\mathrm{T}$, TO R KAMAN $\mathrm{G}$, MOVASSEGHE $\mathrm{S}$, et al. Effects of short-term aerobic exercise with and without external loading on bone metabolism and balance in postmenopausal women with osteoporosis[J]. R heumatology international,2013,33(2)2:291298.

[4] Han Yajun, Tie Xiaojia, Elihami Tohoti. Meta Analysis of Osteoporosis Morbidity among Middle Aged and Elderly People in China [J], Chinese Journal of Tissue Engineering Research, 2014, 18(7): 1129-1134

[5] HOSNY I A, ELGHAWABI H S, YOUNAN W B, et al. Beneficial impact of aerobic exercises on bone mineral density in obese premenopausal women under caloric restriction [J].Skeletal radiology,2012,41(4):423-427.

[6] BU R GE R S T A,WILLIAMS B O. R egulation of Wnt/beta-catenin signaling within and from osteocytes [J].Bone,2013,54(2): 244-249.

[7] Zou Jun, Zhang Lan, Ren Hong. Expert Consensus on Prevention of Osteoporosis through Sports [J], Chinese Journal of Osteoporosis, 2015, 21(11): 1291-1306

[8] KRUM S A. Direct transcriptional targets of sex steroid hormones in bone[J].Journal of cellular biochemistry,2011,112(2):401-408.

[9] Zhang Lin, Yang Xirang, Xue Yan. Research Progress on Sports and BMD Changes of People [J], Journal of Beijing Sport University, 2000, 23 (1): 64-66

[10] DEVLIN M J Estrogen, exercise and the skeleton[J].Evolutionary anthropology, 2011,20(2):54-61.

[11] Faulkner RA, Bailey DA, Drink water DT,et al. Regional and total bone mineral content bone mineral density and total body tissue composition in children 8-16 years of age[J]. Calcif Tissue Int, 1993,53:7-12.

[12] WHITE FORD J,ACKLAND T R,DHALIWAL S S, et al.Effects of a 1-year randomized controlled trial of resistance training on lower limb bone and muscle structure and function in older men[J].Osteoporosis International,2010,21(9)1529-1536.

[13] MON R OE D G,MCGEE-LAW R ENCE M E,OU R SLE R M J, et al.Update on Wnt signaling in bone cell biology and bone disease[J]. Gene,2012,492(1):1-18.

[14] Zhong Jing, Li Yingming, Xu Huiming. Relationship between Feminine Body Weight, Mass of Body Fat, Muscle force of Lower Limbs and BMD [J], Chinese Journal of Misdiagnostics, 2006, 6(11): 2058-2059 